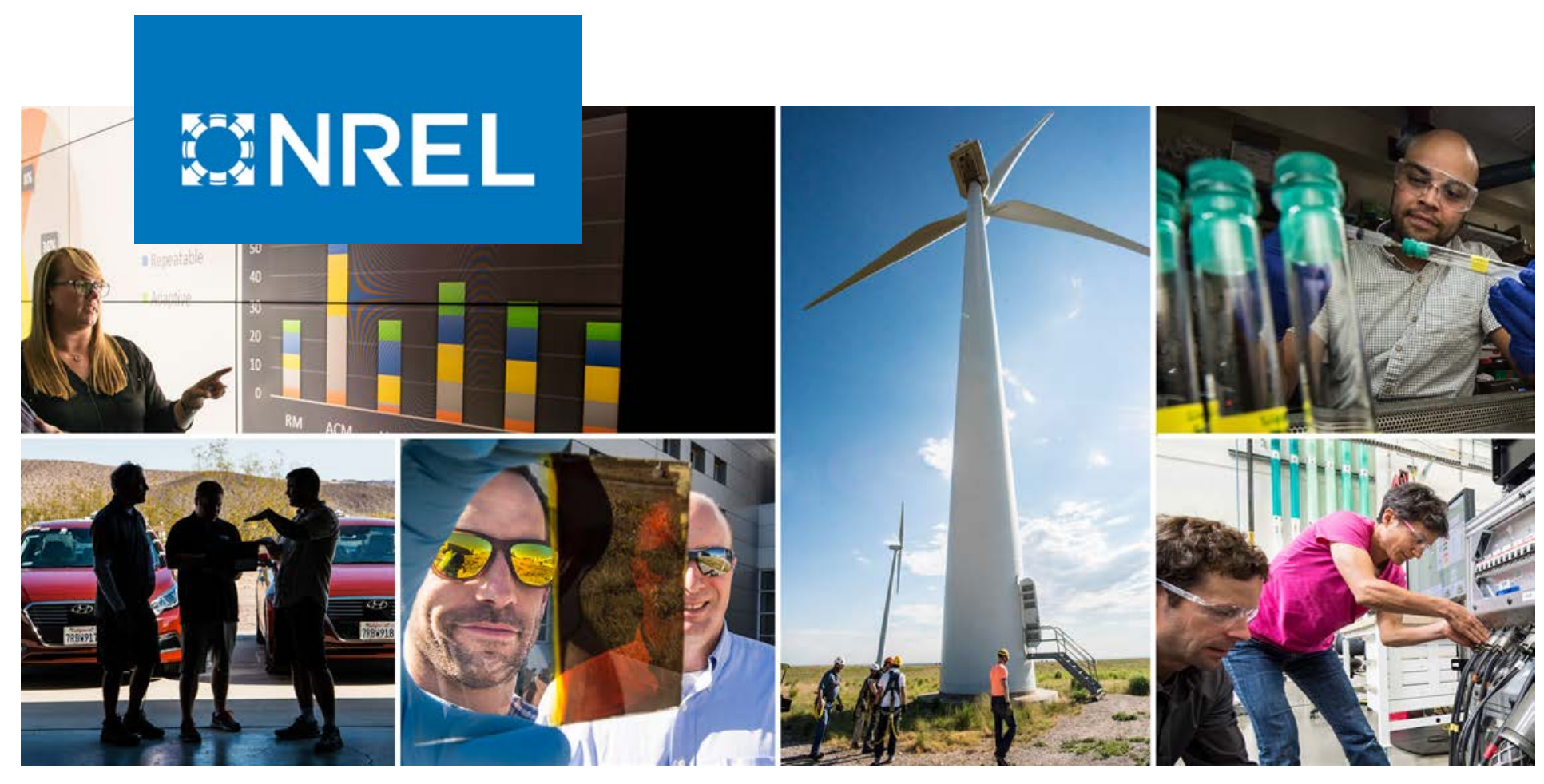

\title{
Metals Analysis of Biodiesel Blends
}

Teresa L. Alleman, Lisa Fouts, and Earl D. Christensen

National Renewable Energy Laboratory

NREL is a national laboratory of the U.S. Department of Energy

Office of Energy Efficiency \& Renewable Energy

Operated by the Alliance for Sustainable Energy, LLC

This report is available at no cost from the National Renewable Energy Laboratory (NREL) at www.nrel.gov/publications.

\section{Technical Report}

NREL/TP-5400-72341

May 2019 


\title{
GHREL
}

\section{Metals Analysis of Biodiesel Blends}

\author{
Teresa L. Alleman, Lisa Fouts, and Earl D. Christensen
}

National Renewable Energy Laboratory

Suggested Citation

Alleman, Teresa L., Lisa Fouts, and Earl D. Christensen. 2019. Metals Analysis of

Biodiesel Blends. Golden, CO: National Renewable Energy Laboratory.

NREL/TP-5400-72341. https://www.nrel.gov/docs/fy19osti/72341.pdf.

NREL is a national laboratory of the U.S. Department of Energy Office of Energy Efficiency \& Renewable Energy Operated by the Alliance for Sustainable Energy, LLC

This report is available at no cost from the National Renewable Energy Laboratory (NREL) at www.nrel.gov/publications.

Contract No. DE-AC36-08GO28308
Technical Report NREL/TP-5400-72341 May 2019

National Renewable Energy Laboratory 15013 Denver West Parkway Golden, CO 80401

303-275-3000 • www.nrel.gov 


\section{NOTICE}

This work was authored by the National Renewable Energy Laboratory, operated by Alliance for Sustainable Energy, LLC, for the U.S. Department of Energy (DOE) under Contract No. DE-AC36-08G028308. Funding provided by the U.S. Department of Energy Office of Energy Efficiency and Renewable Energy Vehicle Technologies Office and the National Biodiesel Board under Cooperative Research and Development Agreement CRD-15-593. The views expressed herein do not necessarily represent the views of the DOE or the U.S. Government.

This report is available at no cost from the National Renewable Energy Laboratory (NREL) at www.nrel.gov/publications.

U.S. Department of Energy (DOE) reports produced after 1991 and a growing number of pre-1991 documents are available free via www.OSTI.gov.

Cover Photos by Dennis Schroeder: (clockwise, left to right) NREL 51934, NREL 45897, NREL 42160, NREL 45891, NREL 48097, NREL 46526.

NREL prints on paper that contains recycled content. 


\section{Acknowledgments}

Co-funding for this work was provided by the National Biodiesel Board under CRADA No. CRD-15-593.

The authors wish to acknowledge Ted Sears from NREL's Federal Fleet Program and the various EPAct fleets that provided samples to make this project possible. The authors also acknowledge Dr. Greg Gililland and Dr. Jenny Nelson from Agilent Technologies and Dr. Francisco LinaresLopez from Chevron for assistance running samples in this project. 


\section{Nomenclature or List of Acronyms}

ASTM

Bxx

$\mathrm{Ca}$

EPA

$\mathrm{Fe}$

ICP-AES

ICP-MS

$\mathrm{K}$

LOD

LOQ

$\mathrm{Mg}$

MP-AES

$\mathrm{Na}$

NREL

$\mathrm{P}$

ppm

vol\%
ASTM International

Biodiesel blend, where $\mathrm{xx}$ is the percent biodiesel, by volume, in the blend

calcium

U.S. Environmental Protection Agency

iron

inductively coupled plasma atomic emission

spectroscopy

inductively coupled plasma mass spectrometer

potassium

limit of detection

limit of quantitation

magnesium

microwave plasma atomic emission spectroscopy

sodium

National Renewable Energy Laboratory

phosphorus

parts per million

percent by volume 


\section{Executive Summary}

ASTM International (ASTM) Specification D6751 limits the concentrations of sodium + potassium and calcium + magnesium to 5 parts per million ( $\mathrm{ppm}$ ) maximum and phosphorus to $10 \mathrm{ppm}$ maximum. Metals are controlled because of the potential for abrasive solids to contribute to engine component wear, for soluble soaps to cause filter clogging and injector deposits, and the additional diesel particle filter ash loading from biodiesel metals may be an issue.

ASTM D6751 relies on two methods for metals determination in biodiesel, both based on inductively-coupled plasma atomic emission spectroscopy (ICP-AES). The limits on metals are meant to be protective when biodiesel is used in blends. No limit exists on metals in the biodiesel blend specification, ASTM D7467 (6-20 percent biodiesel by volume). Current test methods have some significant limitations when trying to get the lowest possible detection limits, as the limit of detection is $1 \mathrm{ppm}$.

The focus of this study was to measure the metal content in real-world biodiesel blends using a variety of analytical methodologies, selected for the lowest detection limits available. In this survey, we applied methods with lower detection limits to provide a more quantitative understanding of potential impacts on particle filter performance. Samples of B20 were collected from various fleets federally mandated to use B20 and public stations throughout the United States. It was assumed the $\mathrm{B} 100$ was solely responsible for the metal content in the $\mathrm{Bxx}^{1}$ blends. Using the biodiesel content, the metal content in the B100 was extrapolated to determine if the biodiesel likely met the limits in ASTM D6751 prior to blending with diesel fuel. The average biodiesel content in this study was 18 vol\% (B18).

Samples were analyzed by a variety of ICP-AES methods, an emerging microwave plasma (MP)-AES method, and an ion chromatography method. UOP-389, an ICP-AES wet ashing method, showed the best results of the ICP methods and was used to test all samples in this study. To provide a robust comparison, the samples were also run on MP-AES and ICP-mass spectrometric (MS) methods.

All methods investigated provided lower limits of detection than those currently used for metals determination in biodiesel. Differences in the results between the methods may be caused by myriad factors, e.g., small differences in ionization efficiency may impact results at these very low levels for the elements of interest. Another key factor may be the different preparation techniques. Our work shows some disagreement may exist between methodologies that needs to be further investigated.

With one exception, metal contents were very low and often at or below the detection limits of the methods. Good directional agreement was observed among the methods. Some variability was expected due to very low levels of metals present. Beyond one sample with very high calcium by all methods, the techniques showed some discrepancies for this element. Each method showed several samples with notable calcium content, although the agreement between methods was not as great as with the other elements.

\footnotetext{
${ }^{1}$ Biodiesel blend, where $\mathrm{xx}$ is the percent biodiesel by volume in the blend.
} 
In total, thirty-five B20 samples collected from public stations and mandated fleets around the United States were tested for metal content using three different methods. Two of the methods were based on ICP, with one using ICP-AES after ashing and the other was direct analysis by ICP-MS. The third analytical method was MP-AES, an emerging alternative to ICP-AES.

Follow-up work should continue to collect data on metal contents of field B20 samples. Having a better understanding of the overall quality of B20 should be useful going forward as one tool to assist in the investigation of the useful life of diesel aftertreatment. The MP-AES technique is not yet standardized through ASTM, and future work should develop a standard test method for use in industry. Lower detection limits are likely possible with optimization of instrument parameters specific to biodiesel blend samples. 


\section{Table of Contents}

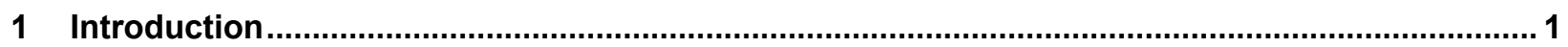

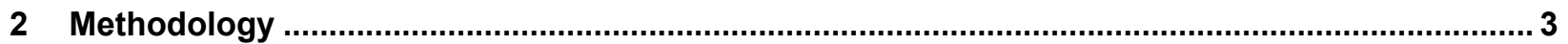

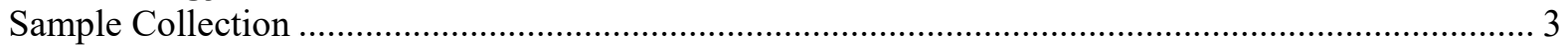

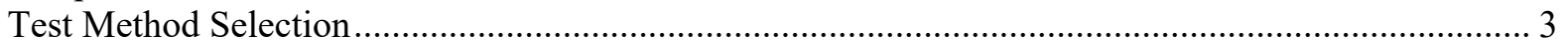

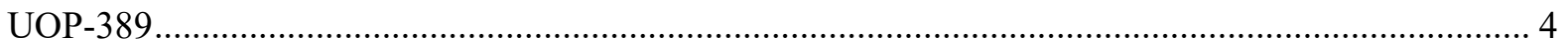

Microwave-Plasma Atomic Emission Spectroscopy (MP-AES) .................................................... 4

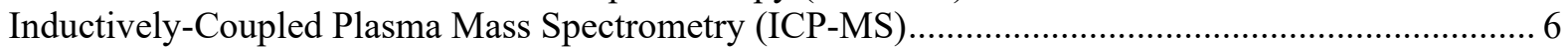

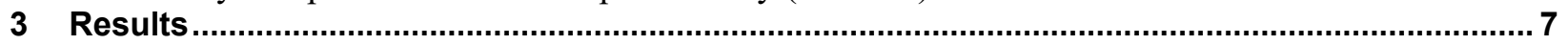

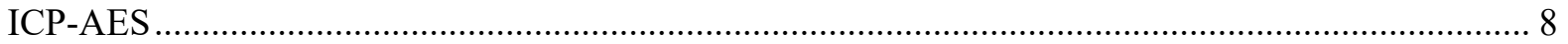

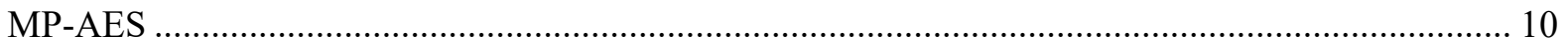

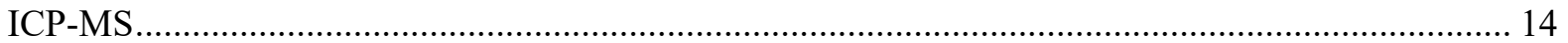

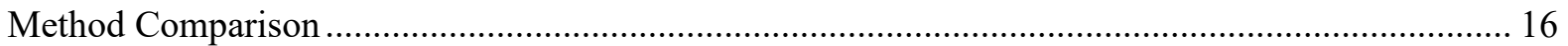

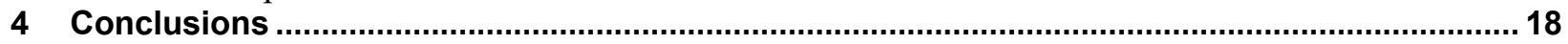

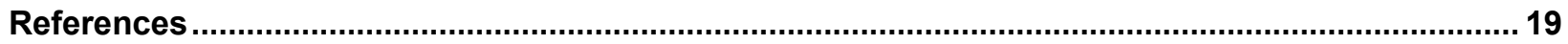

Appendix A 


\section{List of Figures}

Figure 1. State locations of B20 sampling.

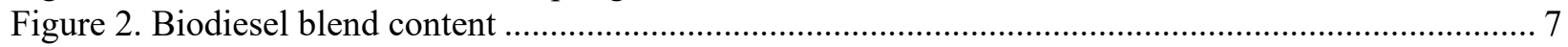

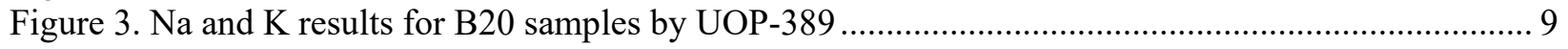

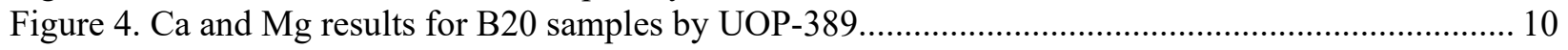

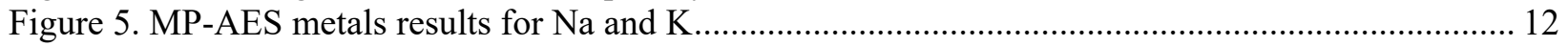

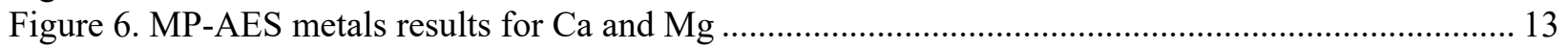

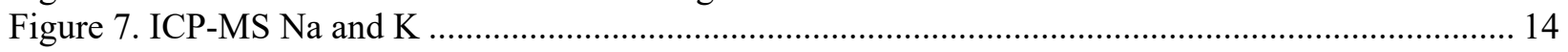

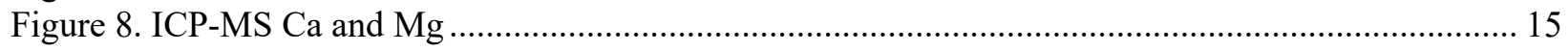

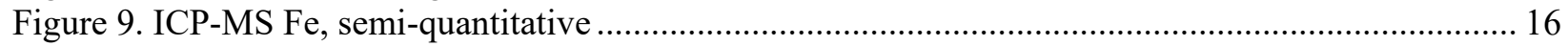

\section{List of Tables}

Table 1. Wavelengths for Detection of $\mathrm{Ca}, \mathrm{K}, \mathrm{Mg}$, and $\mathrm{Na}$ using UOP-389 ........................................... 4

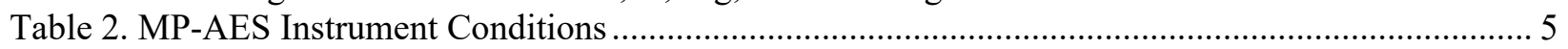

Table 3. Wavelengths for Detection of $\mathrm{Ca}, \mathrm{K}, \mathrm{Mg}$, and $\mathrm{Na}$ using MP-AES ......................................... 5

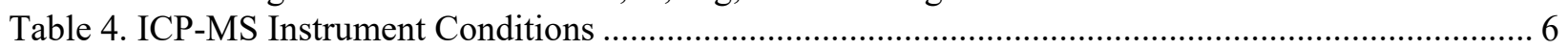

Table A-1. Biodiesel Blend Content Results ................................................................................. 23

Table A-2. Analytical Results and Error Bars for Survey Samples .................................................... 24

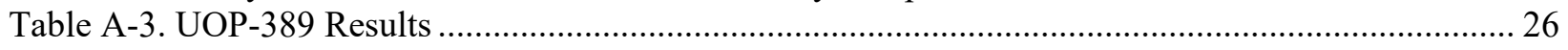

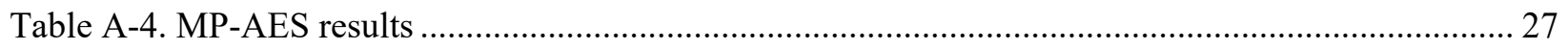

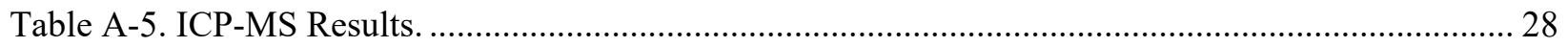




\section{Introduction}

The Renewable Fuels Standard mandated 2.1 billion gallons of biomass-based diesel in 2018, 2.1 billion gallons in 2019 and proposes 2.43 billion gallons in 2020 (U.S. Environmental Protection Agency [EPA] 2018b). Of those mandated gallons, EPA reports biodiesel production of 2.05 billion gallons and non-ester renewable diesel of 0.453 billion gallons in 2017, exceeding the mandate (EPA 2018a). These figures indicate strong growth in the biodiesel market over the past 10 years (National Biodiesel Board 2018). Most biodiesel was used as a blend with petroleum diesel, typically a 20 -volume percent (vol\%) blend or less (biodiesel blends are designated Bxx, where $\mathrm{xx}$ is the volume percent biodiesel in the blend).

The quality of biodiesel and its blends with diesel fuel has been widely reported (McCormick et al. 2004; McCormick et al. 2005; Alleman et al. 2007; Alleman and McCormick 2008; Tang et al. 2008; Geng et al. 2009; Alleman et al. 2010; Alleman et al. 2011; de Guzman et al. 2010; Alleman et al. 2013; Lopes et al. 2014; Legg and Legg, 2015). The surveys collected biodiesel samples, analyzed them for key properties, and compared them to the prevailing ASTM International (ASTM) specifications at the time of the survey. The ASTM specifications have become increasingly stringent over the years as more experience in the use of biodiesel and biodiesel blends has been gained.

Currently, one of the most significant questions about biodiesel quality concerns limits for trace metals. Alkali (sodium $[\mathrm{Na}]$ and potassium $[\mathrm{K}]$ ) and alkaline earth (calcium $[\mathrm{Ca}]$ and magnesium $[\mathrm{Mg}]$ ) metals can be present in biodiesel as residues from the production process. Specification ASTM D6751 limits the combinations of $\mathrm{Na}+\mathrm{K}$ and $\mathrm{Ca}+\mathrm{Mg}$ to 5 parts per million (ppm) maximum and phosphorus (P) to $10 \mathrm{ppm}$ maximum. As discussed in the appendix to ASTM D6751, both groups of metals are controlled because of the potential for abrasive solids to contribute to engine component wear or for soluble soaps to cause filter clogging and injector deposits.

Alkali and alkaline earth metals may also impact diesel catalyst/filter emission control systems and this question is being examined in ongoing research (Williams et al. 2013; Williams et al. 2014; Lance et al. 2016). Recent research (Lance et al. 2016) suggests for heavy-duty systems with a 435,000-mile full-useful-life requirement, the additional diesel particle filter ash loading from biodiesel metals may be an issue depending on the actual levels of $\mathrm{Na}$ and $\mathrm{K}$ found in biodiesel blends on the market. The test method currently used for this determination has a detection limit of $1 \mathrm{ppm}$. Previous surveys of B100 quality have shown most samples have Na and $\mathrm{K}$ levels below detection (Alleman et al. 2013). In this survey we are applying methods with lower detection limits to provide a more quantitative understanding of potential impacts on particle filter performance.

ASTM D6751 relies on two methods for metals determination in biodiesel, both based on inductively-coupled plasma atomic emission spectroscopy (ICP-AES). The specification measures $\mathrm{Ca}, \mathrm{Mg}, \mathrm{Na}$, and $\mathrm{K}$ by EN14538, and $\mathrm{P}$ is measured by ASTM D4951. The limits on metals in ASTM D6751 are meant to be protective when biodiesel is used in blends. No metal limit exists in the biodiesel blend specification, ASTM D7467. 
ASTM D7467 allows for biodiesel content between 6 and 20 vol\%. Previous surveys have found biodiesel content is slightly lower in the winter to allow blenders to meet regional cold flow requirements (Alleman et al. 2011). Federal fleets are required to use a minimum of $20 \mathrm{vol} \%$ biodiesel throughout the year to meet mandates for alternative fuel use.

The current test methods have some significant limitations when trying to get the lowest possible detection limits. The limit of detection of EN14538 is 1 ppm for each metal, and the method includes a statement if the metal is below the limit of detection of the method, it is not included in the reporting calculation. The ASTM D4951 method was originally developed for lubrication oil with much higher metal content than biodiesel. The operating range of the method is $500-$ 1,200 ppm P.

The goal of this study was to measure the metal content in real-world biodiesel blends using a variety of analytical methodologies. These analytical techniques were selected for the lowest detection limits available. 


\section{Methodology}

Samples of B20 were collected from various fleets federally mandated to use B20 and at public stations throughout the United States. Samples were collected in 1-gallon containers and shipped to the National Renewable Energy Laboratory (NREL) for analysis.

\section{Sample Collection}

Thirty-five samples were collected from February through June 2016 throughout the contiguous United States. Nine samples were collected from fleets using B20, and the remaining 26 samples came from retail stations. Many of the retail stations were sampled in the last two weeks of June 2016. Each station was called to confirm they were selling a Bxx blend before a sample was collected. Figure 1 shows where the samples were collected. The blue markers identify retail stations, and the red markers identify fleet locations.

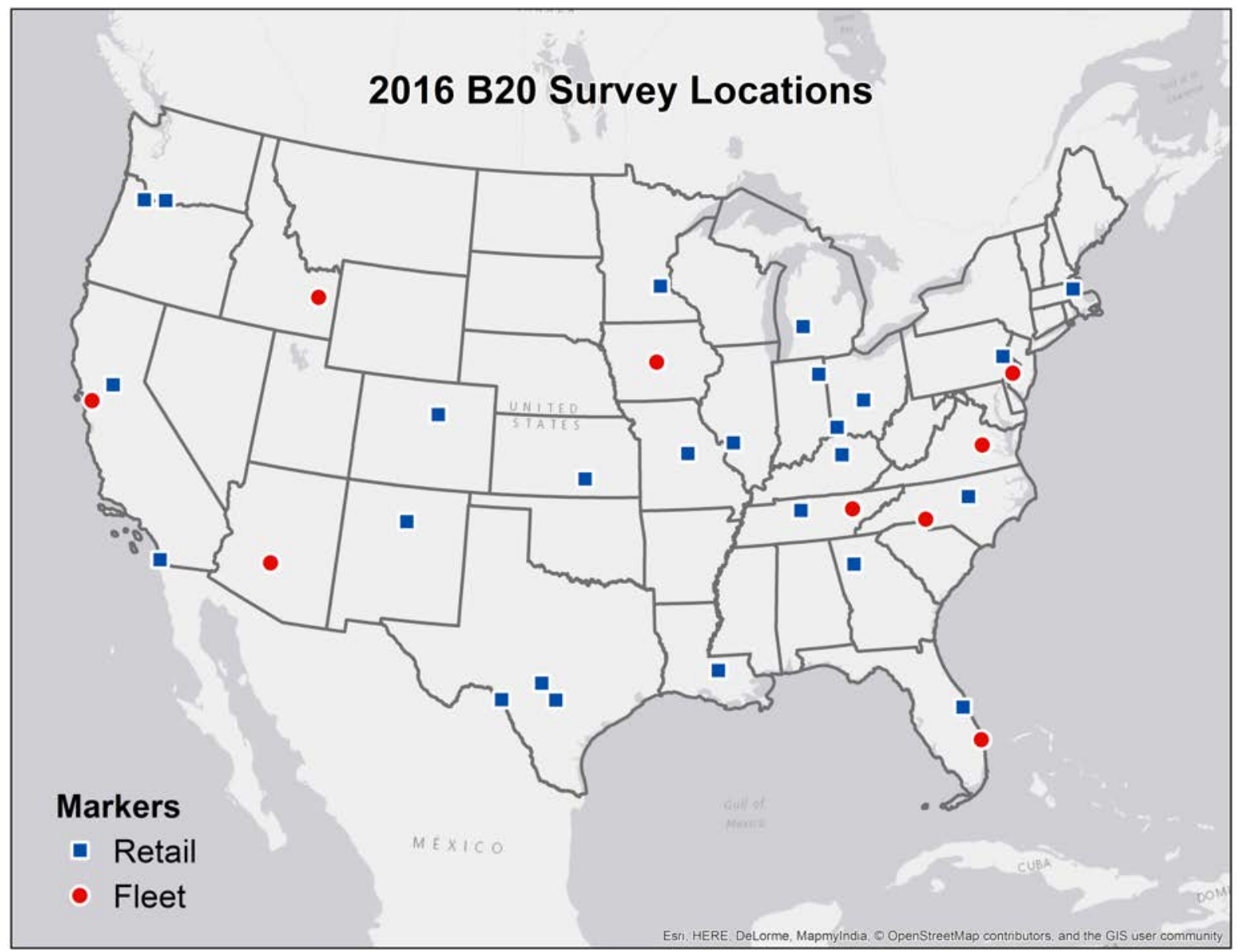

Figure 1. State locations of B20 sampling.

\section{Test Method Selection}

Initially, subsets of five samples were selected and sent for metal analysis by various methodologies. These methods included ICP-AES by UOP-389 and a method based on EPA 6010C. Other potential techniques considered were ion chromatography and microwave plasma 
(MP)-AES. Good improvements in the detection limit of the results were shown by the UOP-389 and MP-AES methods, which are discussed in detail below. The EPA 6010C and ion chromatography methods did not achieve the detection limits necessary for this work, although the techniques are described in Appendix A.

\section{UOP-389}

Based on the screening results, the UOP-389 method (Procedure A) was selected for testing all samples. The commercial lab selected to run the method is BQ-9000 accredited and claimed the ability to provide improved detection limits. UOP-389 Procedure A uses digestion in a sulfur trioxide pyridine complex to produce ash, then dissolution in aqua regia and water prior to ICPAES analysis. Table 1 lists the wavelengths and applicable concentrations for the elements of interest from the UOP-389 method.

Table 1. Wavelengths for Detection of $\mathrm{Ca}, \mathrm{K}, \mathrm{Mg}$, and $\mathrm{Na}$ using UOP-389

\begin{tabular}{ccc}
\hline Element & $\begin{array}{c}\text { Wavelength, } \\
\mathbf{n m}\end{array}$ & $\begin{array}{c}\text { Concentration } \\
\text { Range, ppm }\end{array}$ \\
\hline $\mathrm{Ca}$ & 393.366 & $0.8-5$ \\
$\mathrm{~K}$ & 766.491 & $0.05-500$ \\
$\mathrm{Mg}$ & 279.553 & $0.04-200$ \\
$\mathrm{Na}$ & 589.592 & $0.04-500$ \\
\hline
\end{tabular}

\section{Microwave-Plasma Atomic Emission Spectroscopy (MP-AES)}

An emerging alternative method for elemental analysis is MP-AES. In contrast to ICP-AES, MPAES uses microwaves to generate a nitrogen-based plasma. Sample introduction and detection are similar to ICP-AES. Samples were measured in-house for $\mathrm{Na}, \mathrm{K}, \mathrm{Ca}, \mathrm{Mg}$, and P. Instrument conditions are listed in Table 2. Table 3 lists the recommended detection wavelengths and applicable concentrations for the elements of interest. Additional details of the MP-AES methodology for biodiesel and diesel analysis can be found in Lowenstern and Reisman (2011). 


\section{Table 2. MP-AES Instrument Conditions}

\begin{tabular}{|c|c|}
\hline Parameter & Condition \\
\hline Instrument & $\begin{array}{l}\text { Agilent } 4200 \\
\text { MP-AES }\end{array}$ \\
\hline Nebulizer & Inert, high solids \\
\hline Spray chamber & $\begin{array}{l}\text { Cyclonic } \\
\text { double pass }\end{array}$ \\
\hline Pump tubing & Viton \\
\hline Pump rate & $5 \mathrm{~mL} / \mathrm{min}$ \\
\hline Uptake delay & $60 \mathrm{~s}$ \\
\hline Stabilization time & $45 \mathrm{~s}$ \\
\hline Read time & $10 \mathrm{~s}$ \\
\hline Air injection & Yes \\
\hline $\begin{array}{c}\text { Background } \\
\text { correction }\end{array}$ & Auto \\
\hline Internal standard & 20 ppm yttrium \\
\hline
\end{tabular}

Table 3. Wavelengths for Detection of $\mathrm{Ca}, \mathrm{K}, \mathrm{Mg}$, and $\mathrm{Na}$ using MP-AES

\begin{tabular}{lll}
\hline Element & $\begin{array}{l}\text { Wavelength, } \\
\mathbf{n m}\end{array}$ & $\begin{array}{l}\text { Concentration } \\
\text { Range, ppm }\end{array}$ \\
\hline $\mathrm{Ca}$ & 396.847 & $0-10$ \\
$\mathrm{~K}$ & 766.491 & $0-20$ \\
$\mathrm{Mg}$ & 285.213 & $0-20$ \\
$\mathrm{Na}$ & 588.995 & $0-10$ \\
\hline $\mathrm{P}$ & 213.618 & $1.0-20$ \\
\hline
\end{tabular}




\section{Inductively-Coupled Plasma Mass Spectrometry (ICP-MS)}

Although outside of the scope of this study, an inductively coupled plasma mass spectrometry (ICP-MS) technique was used to validate the other techniques presented in this study. ICP-MS can provide the best detection limits of any method studied, the cost of analysis makes it prohibitive for routine testing when other methods provide adequate detection limits. The results are presented here for comparison. The ICP-MS calibration was set to mirror the calibration used with the MP-AES. In addition to $\mathrm{Na}, \mathrm{Ca}, \mathrm{K}, \mathrm{Mg}$, and $\mathrm{P}$, samples were tested semi-quantitatively for iron (Fe) by ICP-MS. Conditions for the ICP-MS are listed in Table 4.

Table 4. ICP-MS Instrument Conditions

\begin{tabular}{|c|c|c|}
\hline Parameter & \multicolumn{2}{|c|}{ Condition } \\
\hline Instrument & \multicolumn{2}{|c|}{ Agilent 7900} \\
\hline Forward power & \multicolumn{2}{|c|}{$1,550 \mathrm{~W}$} \\
\hline RF matching & \multicolumn{2}{|c|}{$1.8 \mathrm{~V}$} \\
\hline Sample depth & \multicolumn{2}{|l|}{8} \\
\hline Nebulizer gas & \multicolumn{2}{|c|}{$0.45 \mathrm{~L} / \mathrm{min}$} \\
\hline Option gas & \multicolumn{2}{|l|}{$10 \%$} \\
\hline Nebulizer pump & \multicolumn{2}{|c|}{$0.04 \mathrm{rps}$} \\
\hline $\begin{array}{l}\text { Spray chamber } \\
\text { temperature }\end{array}$ & \multicolumn{2}{|c|}{$-2^{\circ} \mathrm{C}$} \\
\hline Dilution gas & \multicolumn{2}{|c|}{$0.10 \mathrm{~L} / \mathrm{min}$} \\
\hline \multicolumn{3}{|l|}{ Collison cell } \\
\hline He mode & \multicolumn{2}{|c|}{$5.0 \mathrm{~mL} / \mathrm{min}$} \\
\hline $\mathrm{H}_{2}$ mode & \multicolumn{2}{|c|}{$6.0 \mathrm{~mL} / \mathrm{min}$} \\
\hline \multirow{6}{*}{$\begin{array}{l}\text { Element isotope } \\
\text { and detection limit }\end{array}$} & ${ }^{40} \mathrm{Ca}$ & $0.5 \mathrm{ppb}$ \\
\hline & ${ }^{56} \mathrm{Fe}$ & a \\
\hline & ${ }^{23} \mathrm{Na}$ & $9.6 \mathrm{ppb}$ \\
\hline & ${ }^{24} \mathrm{Mg}$ & 1.6 ppb \\
\hline & ${ }^{39} \mathrm{~K}$ & $1.25 \mathrm{ppb}$ \\
\hline & ${ }^{31} \mathrm{P}$ & 1.24 ppb \\
\hline
\end{tabular}

ppb: parts per billion

${ }^{a}$ Fe results were semi-quantitative. 


\section{Results}

The primary focus of this work was to examine the metal content of the B20 samples; however, other properties of interest were also measured. The biodiesel blend content, measured using ASTM D7371, is presented in Figure 2 (numerical results are in Table A-1. Data is arranged by Petroleum Area Defense District from I to V [top to bottom] and then alphabetically, with a line delineating each region). It was assumed the B100 was solely responsible for the metal content in the Bxx blends. Using the biodiesel content, the metal content in the B100 was extrapolated to determine if the biodiesel likely met the limits in ASTM D6751 prior to blending with diesel fuel. Other analytical properties for the Bxx blends are given in Table A-2.

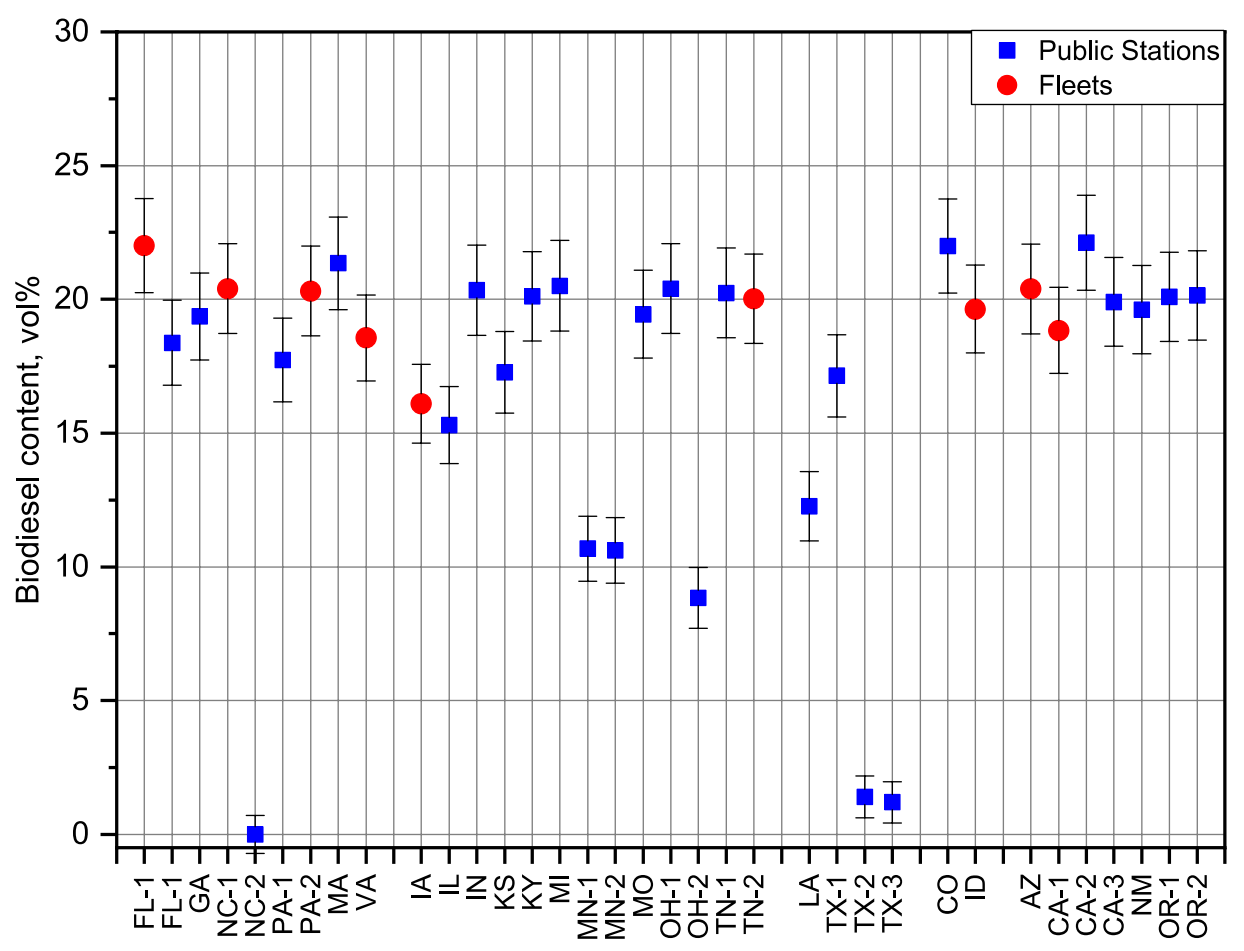

Figure 2. Biodiesel blend content

Diesel fuel may contain up to 5 vol\% biodiesel with no requirements for labeling or disclosure of the biodiesel content (16 Code of Federal Regulations [CFR] Part 306). Notable exceptions are the states of Minnesota and Oregon, which mandate B5 year-round, and Washington State, which mandates B2 (Transportation Environmental Resource Center undated). At the time of this work, Minnesota required B10 from April 1 through September 30, and only B10 was readily available during the study period (Minnesota Department of Agriculture 2018). The B20 mandate for Minnesota was planned to go into effect May 1, 2018, but was temporarily suspended until June 30, 2018 (Minnesota Department of Commerce 2018). 
With no requirement to disclose the volume of biodiesel in conventional diesel fuel, blenders have three options when making biodiesel blends for retail. First, measure the biodiesel content of the diesel fuel being used in blending to precisely determine how much biodiesel is needed to make a B20 blend (samples that are B20). Second, assume the diesel fuel contains $5 \mathrm{vol} \%$, and blend no more than $15 \mathrm{vol} \%$ additional biodiesel (samples that are $\sim \mathrm{B} 17$, for example, were likely blended under this assumption, but the diesel fuel was a B2), or simply add $20 \mathrm{vol} \%$ biodiesel (samples slightly above B20).

The average biodiesel content in this study was 18 vol\%. Three stations had less than 2 vol\% biodiesel. Each of these three stations was contacted prior to sample collection and confirmed they were selling biodiesel. It is unclear why these samples did not contain any biodieselwhether between the time of contact and collection (typically less than 2 weeks) the station stopped selling Bxx blends for whatever reason, whether there was some misunderstanding about the blend being sold when the station was contacted, etc.

\section{ICP-AES}

The UOP-389 method was developed for the analysis of petroleum products and blending components, including biodiesel blends. This, along with the improved detection limits, were the primary reasons the method was selected for this project. The commercial lab that ran the UOP389 method reported a detection limit of $0.1 \mathrm{ppm}$ for all elements tested ( $\mathrm{Na}, \mathrm{K}, \mathrm{Ca}$, and $\mathrm{Mg}$ ), although the method states slightly lower detection limits are possible (Table 1).

The first results provided by the laboratory showed the metal content of most samples below the limit of detection (LOD) of $0.1 \mathrm{ppm}$. However, the laboratory agreed to provide uncertified, "out of scope" results. These results were below the lowest calibration point of the method, but still showed a measurable peak above the signal to noise of the instrument (samples with results below the limit of quantitation [LOQ] of the method but having detectable metals content). These results are presented in Figures 3 and 4 and Table A-3. 


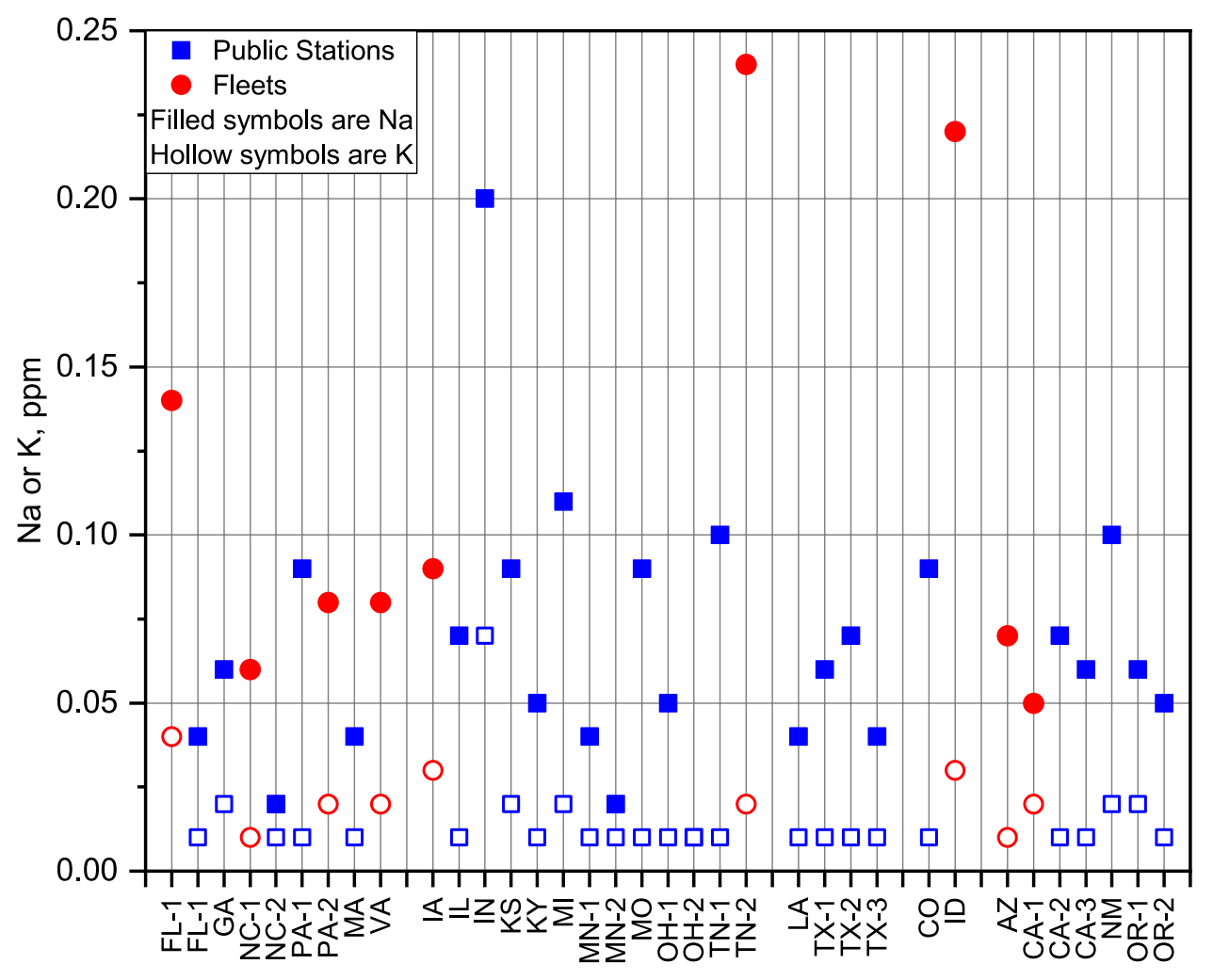

Figure 3. $\mathrm{Na}$ and $\mathrm{K}$ results for $\mathrm{B} 20$ samples by UOP-389 


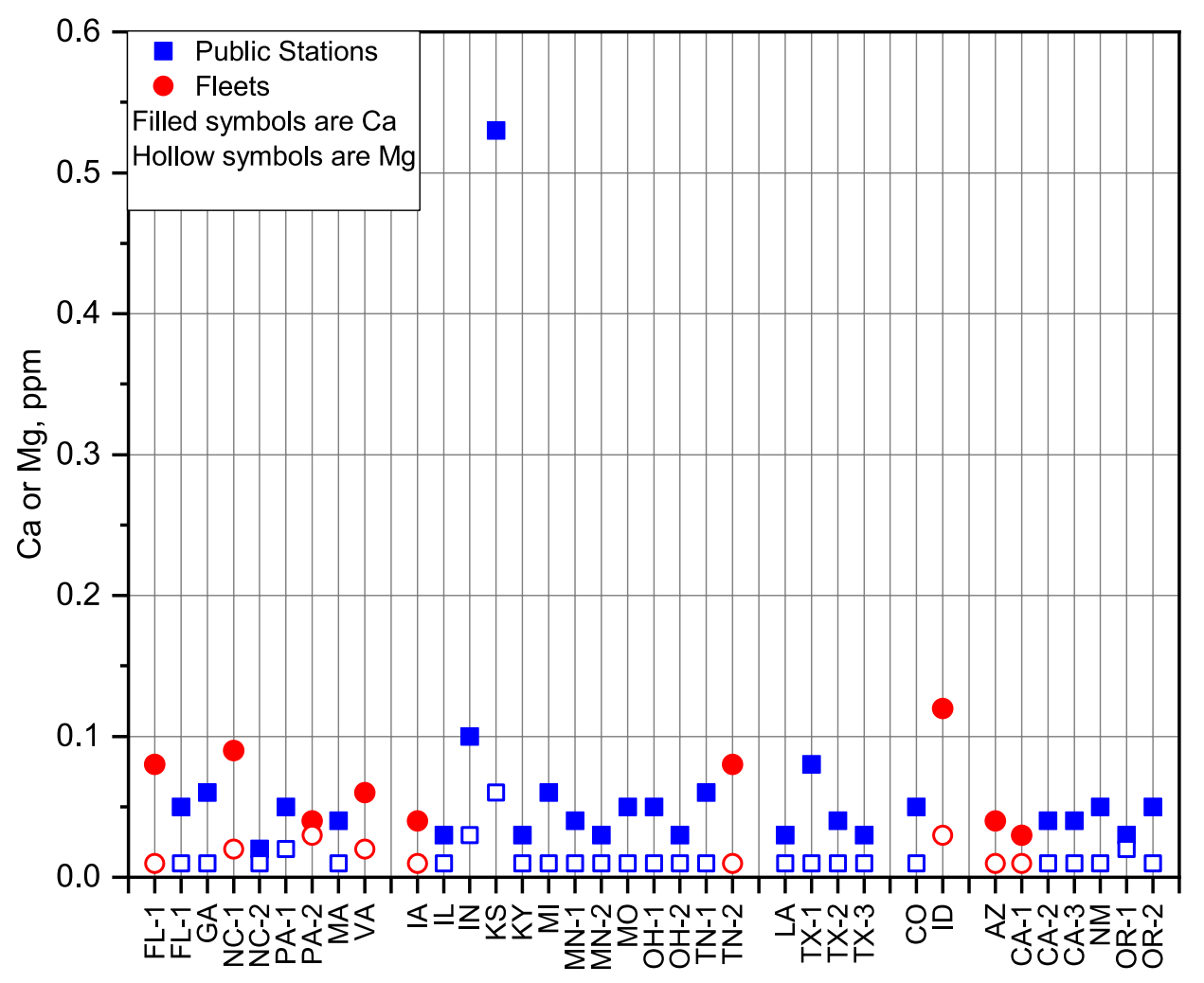

Figure 4. Ca and Mg results for B20 samples by UOP-389.

Sodium was near or below the stated LOQ for every sample, with the exception of samples TN2, ID, and IN. None of the samples had K or Mg above the LOQ. Only samples ID and KS had detectable $\mathrm{Ca}$ present in the sample. Assuming the Ca present in the sample came only from the biodiesel, the Ca content of the KS B100 can be extrapolated to $2.65 \mathrm{ppm}$. While the KS B100 would not be off specification at this level, detectable metals have not typically been observed in previous biodiesel blend quality survey work (Geng et al. 2009; Alleman et al. 2013; Alleman et al. 2011; Alleman et al. 2010).

\section{MP-AES}

MP-AES is a new analytical technique emerging as an alternative to ICP-AES for metal detection. Currently, a standard method for analysis of metals in fuels does not exist although the method standardization process has begun through ASTM.

Results from the MP-AES (Appendix Table A-4 and Figures 5 and 6) show similar results to the ICP-AES, with very low levels of metals for most samples. Phosphorus was not plotted due to only one sample having measured P content. 
To determine the limit of blank (i.e. noise) on our instrument, the same blank sample was measured 10 times at each wavelength. Under these operating conditions, the limits of blank were: $0.413 \mathrm{ppm}$ for $\mathrm{P}, 0.045 \mathrm{ppm}$ for $\mathrm{Mg}$, and $0.023 \mathrm{ppm}$ for $\mathrm{Ca}, \mathrm{K}$, and $\mathrm{Na}$. With further modification of the instrument parameters, improved limits may be possible. Similar to the UOP389 method, several samples had measurable peaks and are reported here.

Only sample KS had Na content above the LOQ/LOD of the method. The P content of the KS sample was measured by the instrument software, but was below the LOQ reported for this method. The K content of several samples was above the LOQ/LOD (GA, KS, IN, IA, CO, ID, OR-1, and CA-1) although in most cases the levels were very low.

Fleet sample FL-1 had detectable $\mathrm{K}$ content below the LOQ, but is reported as 0 here due to uncertainty in the measurement. Samples KS, IN, and ID had at least $0.1 \mathrm{ppm}$ K content. Similar results were observed for $\mathrm{Ca}$ and $\mathrm{Mg}$, with samples that had detectable $\mathrm{K}$ content also having detectable $\mathrm{Ca}$ and $\mathrm{Mg}$ content.

Similar to the ICP-AES results, sample KS was notable for having the highest total metal content of any sample tested by MP-AES. Although the sample contained K, the extrapolated levels in the B100 would still be well below the specification limits. In contrast to the results from the ICP-AES, the results from the MP-AES showed the extrapolated $\mathrm{Ca}+\mathrm{Mg}$ content of sample KS would have been well in excess of the 5-ppm limit in D6751 (nearly $10 \mathrm{ppm}$ ). The sample from $\mathrm{IN}$, a B10, had elevated $\mathrm{K}$ content of 2 ppm extrapolated to the B100. 


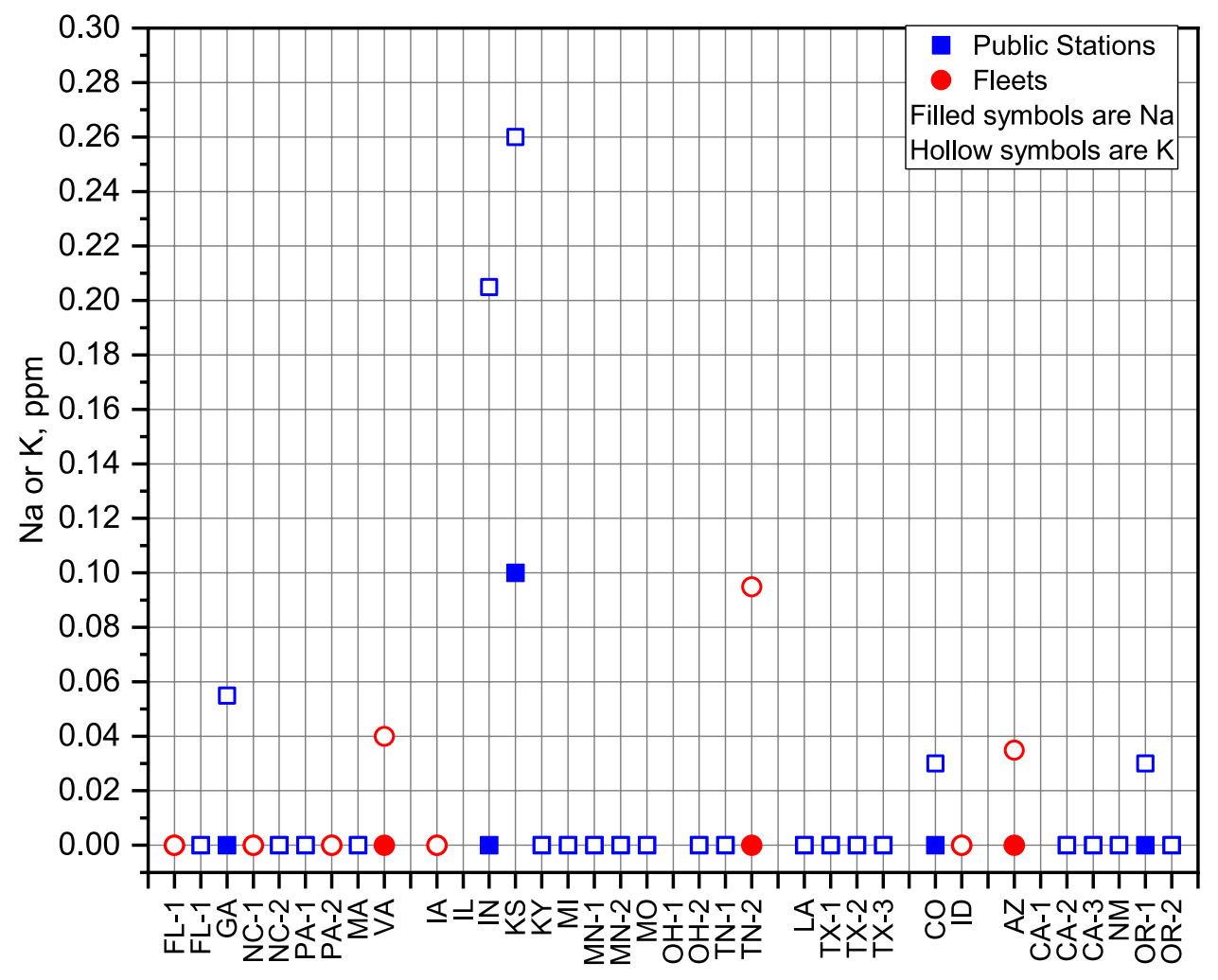

Figure 5. MP-AES metals results for $\mathrm{Na}$ and $\mathrm{K}$ 


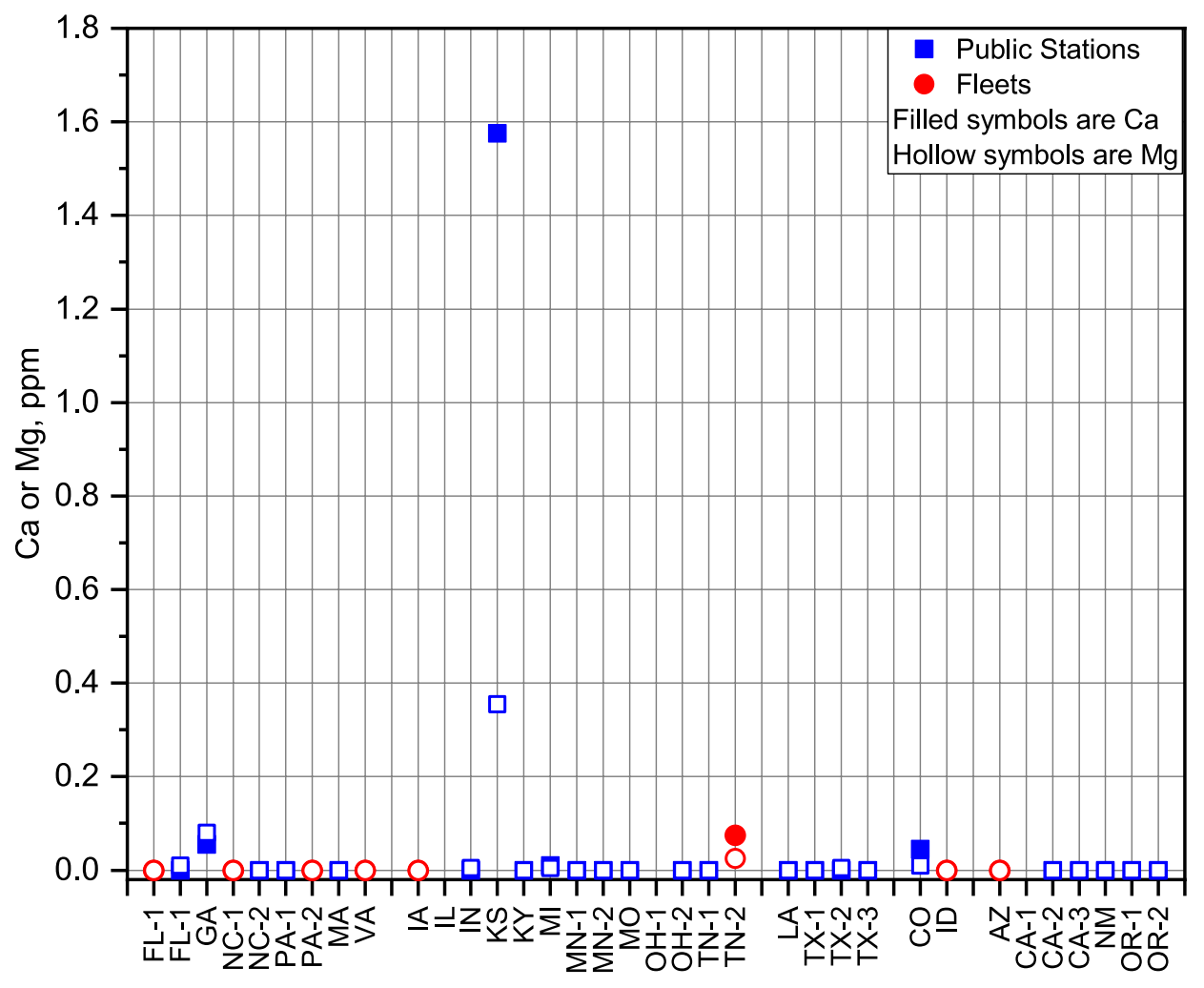

Figure 6. MP-AES metals results for $\mathrm{Ca}$ and $\mathrm{Mg}$ 


\section{ICP-MS}

ICP-MS offered the lowest LOQ/LOD of any technique studied, approximately $0.001 \mathrm{ppm}$ for P, $\mathrm{K}$, and $\mathrm{Mg}$; $0.009 \mathrm{ppm}$ for $\mathrm{Na}$; and $0.0005 \mathrm{ppm}$ for $\mathrm{Ca}$. Table A-5 and Figures 7, 8, and 9 illustrate the results from the ICP-MS determination. The ICP-MS analysis included P and Fe, in addition to $\mathrm{Na}, \mathrm{K}, \mathrm{Ca}$, and $\mathrm{Mg}$. Phosphorus results are not shown because only two samples had detectable $\mathrm{P}$ content.

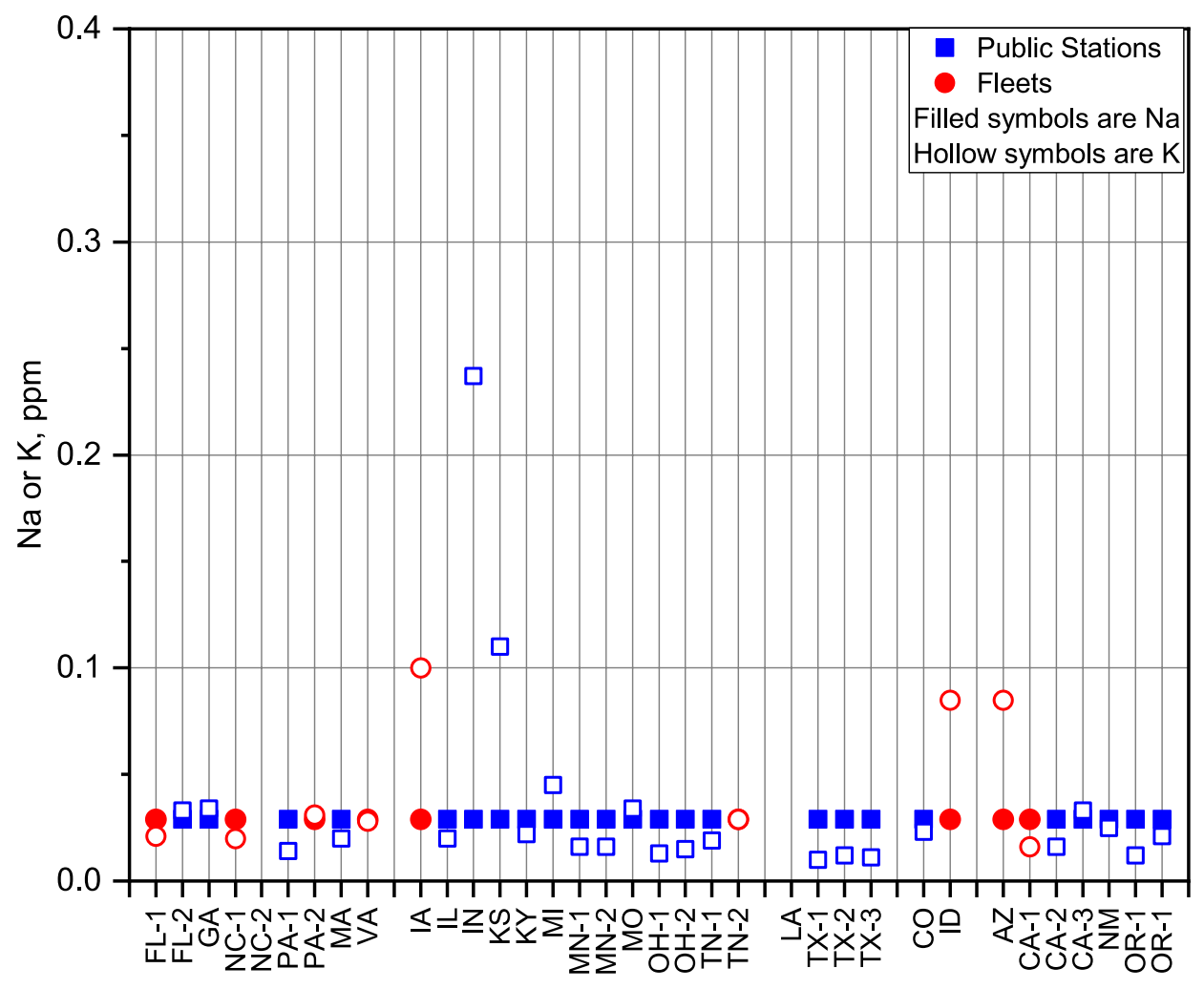

Figure 7. ICP-MS Na and $\mathrm{K}$ 


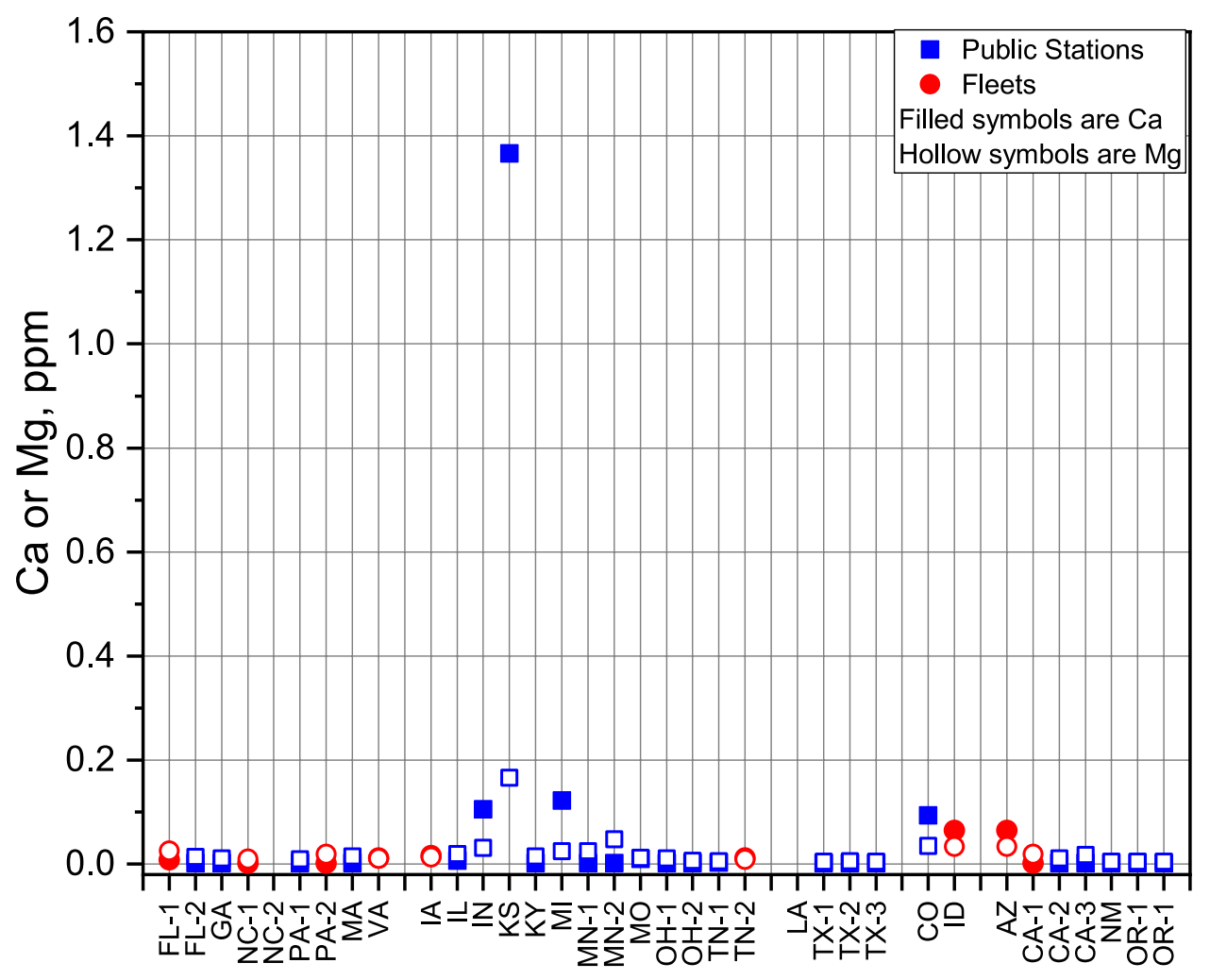

Figure 8. ICP-MS $\mathrm{Ca}$ and $\mathrm{Mg}$

Similar to the other analytical techniques, no samples contained measurable $\mathrm{Na}$, and only samples KS and CO had P above the detection limit. Note the MP-AES did not measure P above the detection limit for these samples. While most samples contained measurable $\mathrm{K}$, samples from KS and IN had the highest levels by ICP-MS and are very similar to the levels measured by MPAES.

Although several samples contained trace amounts of $\mathrm{Ca}$ and $\mathrm{Mg}$ (KS, MI, IN, and $\mathrm{CO}$ ), the levels would have been very low in the B100, with the exception of sample KS. As with the other analytical techniques, sample KS had significant $\mathrm{Ca}$ content (1.37 ppm), making the B100 $\mathrm{Ca}+\mathrm{Mg}$ content significantly above the D6751 limits. The Mg content of sample KS by ICP-MS was roughly half of the level reported by MP-AES. 


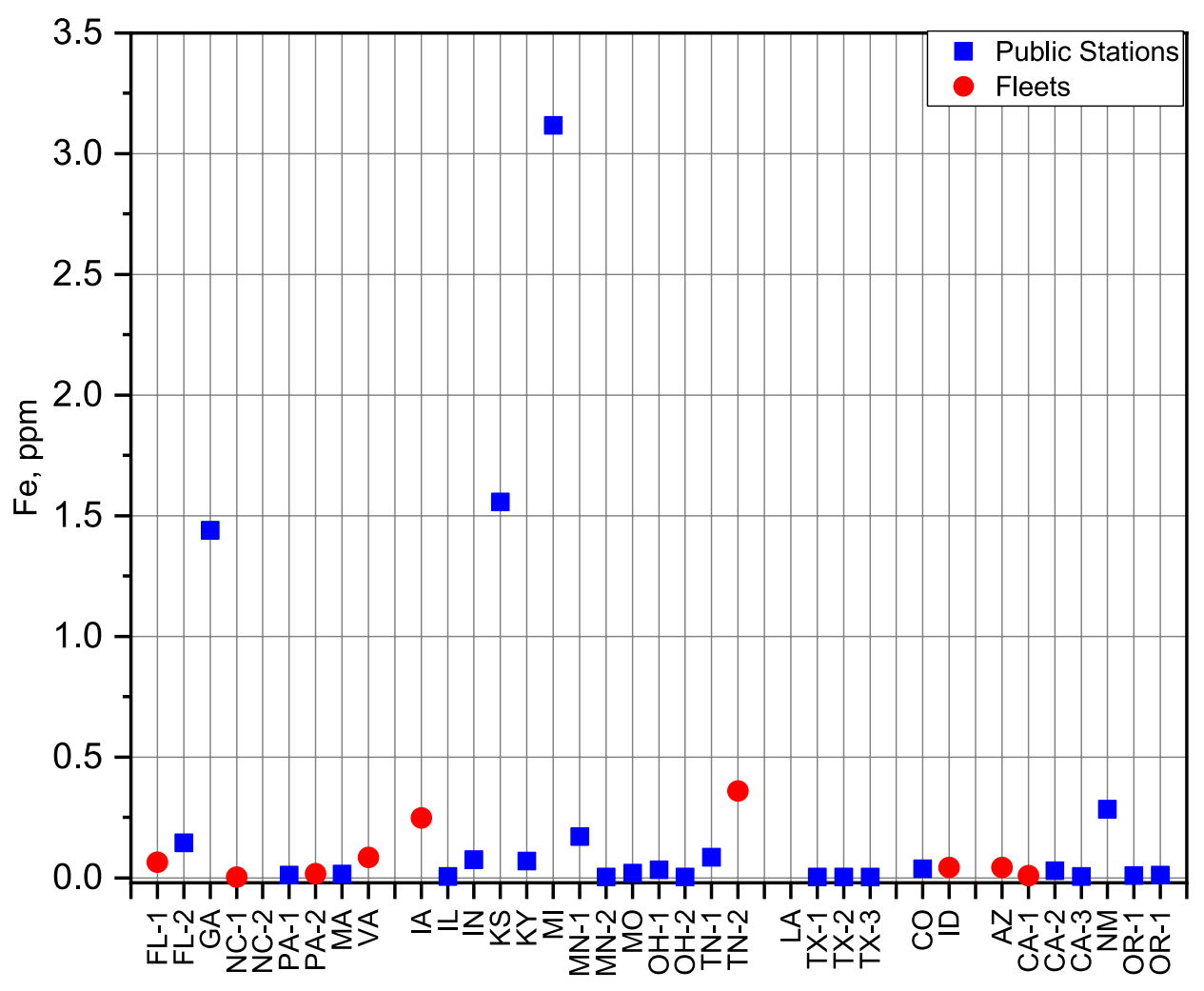

Figure 9. ICP-MS Fe, semi-quantitative

The Fe content of the samples was only tested by ICP-MS, and results are semi-quantitative. The metal content of sample KS as over $1.5 \mathrm{ppm}$, indicating an obvious quality problem with either the sample or the sampling location or both. Other samples with Fe content above $1 \mathrm{ppm}$ were samples GA and MI.

This survey contains a very limited number of samples, and no correlations can be made between Fe content and any other parameter in the study. Iron is not a metal used for biodiesel production, and any $\mathrm{Fe}$ in the samples was most likely picked up in the distribution system or during sample collection, though every effort was made to minimize contamination during collection and analysis.

\section{Method Comparison}

All methods investigated provided lower limits of detection than those currently used for metal determination in biodiesel. Differences in the results between the methods may be caused by myriad factors. Each element has a unique ionization efficiency, and small differences may impact results at these very low levels for the elements of interest. Another key factor may be the different preparation techniques, with the UOP-389 method using digestion and ashing, while MP-AES and ICP-MS used a simpler preparation of sample dilution and direct analysis. 
Sodium was only detected by the UOP-389 method and was not observed above the detection limits for either the MP-AES or ICP-MS methods. The work by Lance et al. (2016) suggests the need for highly accurate Na determination in biodiesel blends. Our work shows there may be some disagreement between methodologies that needs to be further investigated.

The ICP-MS and UOP-389 methods both found very low levels of $\mathrm{K}$ in a majority of samples. The MP-AES found K in $25 \%$ of the samples (FL-1, GA, KS, IN, IA, CO, ID, OR-1, and CA-1). Using the UOP-389 method, the sample from IN had the highest $\mathrm{K}$ content. This sample from $\mathrm{IN}$, as well as the sample from KS, had elevated K using ICP-MS and MP-AES.

All three methods showed the sample from KS sample having Ca content well above every other sample tested. The UOP-389 method showed the lowest $\mathrm{Ca}(0.53 \mathrm{ppm})$ compared to the MPAES and ICP-MS ( 1.5 ppm) in this sample. Beyond this sample with very high $\mathrm{Ca}$, the techniques showed some discrepancies. Each method showed several samples with notable $\mathrm{Ca}$ content, and the agreement between methods was not as great as with the other elements.

The Mg determination showed good agreement between methods, with all three techniques showing elevated $\mathrm{Mg}$ in the sample from KS. Absolute agreement among the methods was poor, with the UOP-389 method showing the lowest Mg content (0.06 ppm), ICP-MS having intermediate levels $(0.17 \mathrm{ppm})$, and MP-AES having the highest level at $0.36 \mathrm{ppm}$, although these levels are very low in any case.

Only the MP-AES and ICP-MS methods were used to determine P content of the samples. Phosphorus determination at these levels is difficult on the MP-AES, and the reported results are below the detection limit of our instrument. The ICP-MS offered a significantly lower detection limit than the MP-AES for samples and may be necessary if ultra-low P detection is necessary in the future. 


\section{Conclusions}

Thirty-five B20 samples were collected from public stations and mandated fleets throughout the United States. The samples were tested for metal content using three different methods. Two methods were based on ICP, with one using ICP-AES after ashing and the other was direct analysis by ICP-MS. The third analytical method was MP-AES, an emerging alternative to ICPAES.

All three methods were used successfully to determine the metal content of the biodiesel blend samples. With the exception of one sample (KS), metal contents were very low and often at or below the detection limits of the methods. Good directional agreement was observed between the methods and some variability was expected due to the very low levels of metals present.

Due to the nature of the methods, not all metals will have the same limits of detection, and some metals are inherently more difficult to measure due to high ionization potentials. This is especially true for $\mathrm{P}$, though reasonable agreement was achieved between the methods for all samples tested.

Only the B20 sample from KS showed significant metal content in this study. The source of the metal was not investigated, as it was beyond the scope. The levels of metals in this sample were some of the highest observed in recent quality survey work, and it is highly likely the biodiesel was out of specification when blended with the diesel fuel.

Follow-up work should continue to collect data on the metal content of field B20 samples. Due to the long useful life of diesel vehicles, it may be impossible outside of controlled tests to determine direct cause and effect of metals on emission control devices. However, having a better understanding of the overall quality of B20 should be useful to the industry going forward.

The MP-AES technique is not yet standardized through ASTM, and future work should develop a standard test method for use in industry. Lower detection limits are likely possible with optimization of instrument parameters specific to biodiesel blend samples. 


\section{References}

Alleman, T.L., and R.L. McCormick. 2008. Results of the 2007 B100 Quality Survey. Golden, CO: National Renewable Energy Laboratory. Technical report NREL/TP-540-42787. http://www.nrel.gov/docs/fy08osti/42787.pdf.

Alleman, T.L., L. Fouts, and G. Chupka. 2013. Quality Parameters and Chemical Analysis for Biodiesel Produced in the United States in 2011. Golden, CO: National Renewable Energy Laboratory. Technical report NREL/TP-5400-57662. http://www.nrel.gov/docs/fy13osti/57662.pdf.

Alleman, T.L., L. Fouts, and R.L. McCormick. 2011. "Quality Analysis of Wintertime B6-B20 Biodiesel Blend Samples Collected in the United States." Fuel Processing Technology 92, no. 7: 5407-5415.

Alleman, T.L., R.L. McCormick, and S. Deutch. 2007. 2006 B100 Quality Survey Results: Milestone Report. Golden, CO: National Renewable Energy Laboratory. Technical report NREL/TP-540-41549. http://www.nrel.gov/docs/fy07osti/41549.pdf.

Alleman, T.L., L. Fouts, and R.L. McCormick. 2010. Analysis of Biodiesel Blend Samples Collected in the United States in 2008 (Revised). Golden, CO: National Renewable Energy Laboratory. Technical report NREL/TP-540-46592. http://www.nrel.gov/docs/fy11osti/46592.pdf.

Bock, R., A Handbook of Decomposition Methods in Analytical Chemistry. T.\&A. Constable Ltd., Edinburgh. 1979.

de Guzman, R.C., H. Tang, S. Wadumesthrige, T. Zhou, M.D. Garcia-Perez, K.Y.S. Ng, and S.O. Salley. 2010. "2009 Quality Survey of Retail Biodiesel Blends in Michigan." Fuel 89: 3662-3667. https://doi.org/10.1016/j.fuel.2010.07.035

Federal Trade Commission, 16 CFR Part 306, "Automotive Fuel Ratings, Certification, and Posting," https://www.ftc.gov/sites/default/files/documents/federal_register_notices/automotivefuel-rating-certification-and-posting-16-cfr-part-306/080311automotivefuelratings.pdf, accessed August 24, 2016.

Geng, P.Y., A.E. Buczynsky, and A. Konzack. 2009. "US and EU Market Biodiesel Blends Quality Review - An OEM Perspective.” SAE Int. J. Fuels Lubr. 2, no. 1: 860-869. doi:10.4271/2009-01-1850.

Lance, M., T. Toops, R. Ancimer, R., H. An, J. Li, A. Williams, P. Sindler, A. Ragatz, and R.L. McCormick. 2016. "Evaluation of Fuel-Borne Sodium Effects on DOC-DPF-SCR Heavy-Duty Engine Emission Control System: Simulation of Full-Useful Life.” SAE Technical Paper No. 2016-01-2322, doi:10.4271/2016-01-2322.

Legg, R.R., and M.T. Legg. 2015. "Survey of Biodiesel Content at Retail Diesel Fuel Outlets in Illinois and Minnesota." CRC Project No. E-112, www.crcao.org. 
Lopes, S.M., P. Geng, and A. Konzack. 2014. "Review of 2013 U.S. Retail Biodiesel Blends Quality Survey.” SAE Technical Paper 2014-01-1379, doi:10.4271/2014-01-1379.

Lowenstern, P., and E. Reisman. 2011. Analysis of Diesel using the 4100 MP-AES. Application Note. Melbourne, Australia: Agilent Technologies. Publication number: 5990-9005EN, September 1, 2011. https://www.agilent.com/cs/library/applications/59909005EN_AppNote_4100MP-AES_Diesel.pdf.

McCormick, R.L., T.L. Alleman, M. Ratcliff, L. Moens, and R. Lawrence. 2005. Survey of the Quality and Stability of Biodiesel and Biodiesel Blends in the United States in 2004. Golden, CO: National Renewable Energy Laboratory. Technical report NREL/TP-540-38836. http://www.nrel.gov/docs/fy06osti/38836.pdf.

Minnesota Department of Agriculture. 2018. "About the Minnesota Biodiesel Program." http://www.mda.state.mn.us/environment-sustainability/minnesota-biodiesel, accessed August $17,2018$.

Minnesota Department of Commerce. 2018. "Temporary Suspension of Biodiesel Minimum Content Requirement as authorized under Minn. Stat. 239.77, subd. 2(d)." http://mn.gov/commerce-stat/pdfs/temporary-suspension-biodiesel-minimum-requirement.pdf, accessed June 8, 2018.

National Biodiesel Board. 2018. "Production Statistics." http://biodiesel.org/production/production-statistics, accessed May 4, 2018.

Tang, H., N. Abunasser, A. Wang, B.R. Clark, K. Wadumesthrige, S. Zeng, M. Kim, S.O. Salley, G. Hirschlieb, J. Wilson, K.Y.S. Ng. 2008. "Quality Survey of Biodiesel Blends Sold at Retail Stations." Fuel 87: 2951-2955.

Transportation Environmental Resource Center. Undated. "Alternative Fuels - State Regulations Listed by Topic.” http://www.tercenter.org/pages/altfuelcompare.htm, accessed June 8, 2018.

U.S. Environmental Protection Agency. 2007. "Method 6010C (SW-846): Inductively Coupled Plasma-Atomic Emission Spectrometry." Revision 3.

U.S. Environmental Protection Agency. 2018a. "Proposed Volume Standards for 2019, and the Biomass-Based Diesel Volume for 2020." https://www.epa.gov/renewable-fuel-standardprogram/proposed-volume-standards-2019-and-biomass-based-diesel-volume-2020, accessed August 13, 2018.

U.S. Environmental Protection Agency. 2018b. "2017 Renewable Fuel Standard data.” https://www.epa.gov/fuels-registration-reporting-and-compliance-help/2017-renewable-fuelstandard-data, access August 13, 2018.

USP XXIV <231>, Heavy Metals, Method II.

Williams, A., J. Burton, R.L. McCormick, T. Toops, A.A. Wereszczak, E.E. Fox, M.J. Lance, G. Cavataio, D. Dobson, J. Warner, R. Brezny, D.W. Brookshear, and K. Nguyen. 2013. "Impact of 
Fuel Metal Impurities on the Durability of a Light Duty Diesel Aftertreatment System.” SAE Technical Paper No. 2013-01-0513, doi: 10.4271/2013-01-0513.

Williams, A., R.L. McCormick, M.J. Lance, C. Xie, T. Toops, and R. Brezny, R. "Effect of the Acceleration Factor on the Capture and Impact of Fuel-Borne Metal Impurities on Emissions Control Devices.” 2014. SAE Int. J. Fuels Lubr. 7 no. 2, doi:10.4271/2014-01-1500. 


\section{Appendix A}

To fully explore the various metal analysis methods available, subsets of samples were tested using a variety of methods to determine the methods with the lowest detection limit. The three methods that had the lowest detection limits, UOP-389, ICP-MS, and MP-AES, are discussed above. The other methods used are discussed in more detail here.

A standard digestion and analysis by ICP-AES was also used, although not following ASTM methods for fuels (Bock 1979; USP XXIV). The test laboratory followed standard ICP-AES techniques (EPA 2007) for the analysis. Fuels, being a relatively dirtier matrix, will have a higher limit of detection than water, although some improvement over current ASTM methods may be possible. Results from the EPA 6010C method (EPA 2007) show improved detection limits for $\mathrm{P}$, with a detection limit of $<0.9 \mathrm{ppm}$, although results for the other elements of interest are comparable to current methods at approximately $1 \mathrm{ppm}$.

Another method explored was matrix elimination ion chromatography. Samples were prepared by shaking in warm water for 15 minutes and allowed to settle. The aqueous phase was removed and filtered. The metal-containing aqueous phase was injected onto an ion chromatograph with non-suppressed conductivity detection and analyzed for $\mathrm{Na}$. The method detection limit was 0.34 ppm Na, which represented an improvement over current methods, but the long run times $(\sim 40$ minutes) made this a less attractive method for this study. 
Table A-1. Biodiesel Blend Content Results

\begin{tabular}{|c|c|c|}
\hline State & Biodiesel Content, vol\% & Error, vol\% \\
\hline FL-1 (fleet) & 22.01 & 1.76 \\
\hline FL-2 & 18.38 & 1.59 \\
\hline $\mathrm{GA}$ & 19.36 & 1.63 \\
\hline NC-1 (fleet) & 20.40 & 1.68 \\
\hline NC-2 & 0.00 & 0.71 \\
\hline PA-1 & 17.73 & 1.56 \\
\hline PA-2 (fleet) & 20.31 & 1.68 \\
\hline MA & 21.35 & 1.73 \\
\hline VA (fleet) & 18.56 & 1.60 \\
\hline IA (fleet) & 16.10 & 1.48 \\
\hline IL & 15.30 & 1.44 \\
\hline IN & 20.34 & 1.68 \\
\hline KS & 17.27 & 1.53 \\
\hline KY & 20.11 & 1.67 \\
\hline $\mathrm{MI}$ & 20.51 & 1.69 \\
\hline $\mathrm{MN}-1$ & 10.68 & 1.22 \\
\hline $\mathrm{MN}-2$ & 10.61 & 1.22 \\
\hline MO & 19.44 & 1.64 \\
\hline $\mathrm{OH}-1$ & 20.40 & 1.68 \\
\hline $\mathrm{OH}-2$ & 8.84 & 1.13 \\
\hline TN-1 & 20.24 & 1.68 \\
\hline TN-2 (fleet) & 20.02 & 1.67 \\
\hline LA & 12.26 & 1.30 \\
\hline TX-1 & 17.14 & 1.53 \\
\hline TX-2 & 1.40 & 0.78 \\
\hline TX-3 & 1.20 & 0.77 \\
\hline $\mathrm{CO}$ & 21.99 & 1.76 \\
\hline ID (fleet) & 19.64 & 1.65 \\
\hline$A Z$ (fleet) & 20.39 & 1.68 \\
\hline CA-1 (fleet) & 18.84 & 1.61 \\
\hline CA-2 & 22.12 & 1.77 \\
\hline$C A-3$ & 19.90 & 1.66 \\
\hline NM & 19.61 & 1.65 \\
\hline OR-1 & 20.10 & 1.67 \\
\hline OR-2 & 20.15 & 1.67 \\
\hline
\end{tabular}


Table A-2. Analytical Results and Error Bars for Survey Samples

\begin{tabular}{|c|c|c|c|c|c|c|c|c|c|c|c|}
\hline State & $\begin{array}{c}\text { Date } \\
\text { Collected }\end{array}$ & $\begin{array}{l}\text { Cloud } \\
\text { Point, }{ }^{\circ} \mathrm{C} \\
\text { D5773 }\end{array}$ & Error & $\begin{array}{l}\text { Water, } \\
\text { ppm } \\
\text { D6304 }\end{array}$ & Error & $\begin{array}{c}\text { Rancimat, } \\
\text { Hours } \\
\text { EN15751 }\end{array}$ & Error & $\begin{array}{c}\text { Acid } \\
\text { Number, } \\
\text { mgKOH/g } \\
\text { D664 }\end{array}$ & Error & $\begin{array}{c}\text { Peroxide } \\
\text { Number, ppm } \\
\text { AOCS Cd8b-90 }\end{array}$ & Error \\
\hline FL-1 (fleet) & $4 / 15 / 16$ & -9.9 & 0.9 & 155 & 8.7 & 21.3 & 4.4 & 0.07 & 0.06 & 4.9 & 5.0 \\
\hline FL-2 & $6 / 24 / 16$ & -2.3 & 0.9 & 224 & 10.9 & 10.9 & 2.5 & 0.12 & 0.08 & 34.8 & 9.2 \\
\hline $\mathrm{GA}$ & $6 / 20 / 16$ & -0.9 & 0.9 & 216 & 10.7 & 3.2 & 1.0 & 0.12 & 0.07 & 39.7 & 9.9 \\
\hline NC-1 (fleet) & $3 / 24 / 16$ & -10.7 & 0.9 & 119 & 7.5 & 18.2 & 3.8 & 0.05 & 0.05 & 2.0 & 4.5 \\
\hline NC-2 & $6 / 22 / 16$ & -12.7 & 0.9 & 80 & 5.9 & 10.1 & 2.3 & 0.09 & 0.07 & 0.2 & 4.3 \\
\hline PA-1 & $5 / 5 / 16$ & -10.8 & 0.9 & 71 & 5.5 & 21.2 & 4.4 & 0.03 & 0.04 & 1.6 & 4.5 \\
\hline PA-2 (fleet) & $5 / 5 / 16$ & -10.6 & 0.9 & 130 & 7.9 & 17.9 & 3.8 & 0.06 & 0.06 & 10.5 & 5.8 \\
\hline MA & $6 / 23 / 16$ & -12.2 & 0.9 & 141 & 8.3 & 12.4 & 2.7 & 0.13 & 0.08 & 14.3 & 6.3 \\
\hline VA (fleet) & $7 / 7 / 16$ & -6.5 & 0.9 & 249 & 11.6 & 17.4 & 3.7 & 0.08 & 0.06 & 12.9 & 6.1 \\
\hline IA (fleet) & $7 / 28 / 16$ & -10.8 & 0.9 & 117 & 7.4 & 27.04 & 5.5 & 0.04 & 0.05 & 1.5 & 4.5 \\
\hline IL & $4 / 26 / 16$ & -14.3 & 0.9 & 64 & 5.1 & 19.8 & 4.1 & 0.06 & 0.06 & 3.4 & 4.7 \\
\hline IN & $6 / 23 / 16$ & -9.8 & 0.9 & 121 & 7.5 & 29.5 & 6.0 & 0.08 & 0.07 & 5.0 & 5.0 \\
\hline KS & $6 / 22 / 16$ & -3.5 & 0.9 & 209 & 10.5 & 7.6 & 1.8 & 0.18 & 0.09 & 32.7 & 8.9 \\
\hline KY & $5 / 11 / 16$ & -9.3 & 0.9 & 186 & 9.8 & 6.6 & 1.6 & 0.15 & 0.08 & 30.6 & 8.6 \\
\hline $\mathrm{MI}$ & $6 / 23 / 16$ & -14.4 & 0.9 & 233 & 11.2 & 1.7 & 0.7 & 0.12 & 0.08 & 144.3 & 24.8 \\
\hline MN-1 & $6 / 2 / 16$ & -17.9 & 0.9 & 65 & 5.2 & 54.6 & 10.8 & 0.03 & 0.05 & 0.3 & 4.3 \\
\hline $\mathrm{MN}-2$ & $6 / 2 / 16$ & -16.3 & 0.9 & 44 & 4.1 & 56.5 & 11.1 & 0.03 & 0.04 & 0.2 & 4.3 \\
\hline MO & $2 / 29 / 16$ & -18.7 & 0.9 & 65 & 5.2 & 14.6 & 3.1 & 0.09 & 0.07 & 8.0 & 5.4 \\
\hline $\mathrm{OH}-1$ & $2 / 29 / 16$ & -9.3 & 0.9 & 49 & 4.4 & 7.9 & 1.9 & 0.02 & 0.04 & 15.6 & 6.5 \\
\hline $\mathrm{OH}-2$ & $6 / 22 / 16$ & -15.5 & 0.9 & 95 & 6.5 & 13.5 & 3.0 & 0.08 & 0.06 & 1.5 & 4.5 \\
\hline TN-1 & $3 / 18 / 16$ & -10.0 & 0.9 & 182 & 9.6 & 2.3 & 0.8 & 0.14 & 0.08 & 96.3 & 18.0 \\
\hline TN-1 (fleet) & $5 / 20 / 16$ & -11.0 & 0.9 & 145 & 8.4 & 3.2 & 1.0 & 0.16 & 0.09 & 68.4 & 14.0 \\
\hline LA & $6 / 17 / 16$ & -6.9 & 0.9 & 101 & 6.8 & 33.3 & 6.7 & 0.12 & 0.08 & 1.1 & 4.4 \\
\hline TX-1 & $4 / 4 / 16$ & -8.0 & 0.9 & 115 & 7.3 & 21.4 & 4.4 & 0.02 & 0.04 & 11.3 & 5.9 \\
\hline TX-2 & $6 / 19 / 16$ & -10.5 & 0.9 & 58 & 4.8 & 24 & 4.9 & 0.08 & 0.06 & 0.5 & 4.3 \\
\hline TX-3 & $6 / 20 / 16$ & -11.1 & 0.9 & 67 & 5.3 & 24 & 4.9 & 0.04 & 0.05 & 3.7 & 4.8 \\
\hline
\end{tabular}




\begin{tabular}{|c|c|c|c|c|c|c|c|c|c|c|c|}
\hline State & $\begin{array}{c}\text { Date } \\
\text { Collected }\end{array}$ & $\begin{array}{l}\text { Cloud } \\
\text { Point, }{ }^{\circ} \mathrm{C} \\
\text { D5773 }\end{array}$ & Error & $\begin{array}{l}\text { Water, } \\
\text { ppm } \\
\text { D6304 }\end{array}$ & Error & $\begin{array}{c}\text { Rancimat, } \\
\text { Hours } \\
\text { EN15751 }\end{array}$ & Error & $\begin{array}{c}\text { Acid } \\
\text { Number, } \\
\text { mgKOH/g } \\
\text { D664 }\end{array}$ & Error & $\begin{array}{c}\text { Peroxide } \\
\text { Number, ppm } \\
\text { AOCS Cd8b-90 }\end{array}$ & Error \\
\hline $\mathrm{CO}$ & $3 / 4 / 16$ & -11.9 & 0.9 & 77 & 5.7 & 8.8 & 2.1 & 0.05 & 0.05 & 13.6 & 6.2 \\
\hline ID (fleet) & $6 / 10 / 16$ & -17.5 & 0.9 & 71 & 5.5 & 28.7 & 5.8 & 0.11 & 0.07 & 5.0 & 5.0 \\
\hline$A Z$ (fleet) & $4 / 22 / 16$ & -6.0 & 0.9 & 72 & 5.5 & 32.0 & 6.5 & 0.06 & 0.06 & 2.3 & 4.6 \\
\hline CA-1(fleet) & $5 / 13 / 16$ & -13.8 & 0.9 & 89 & 6.3 & 21.9 & 4.5 & 0.07 & 0.06 & 4.1 & 4.8 \\
\hline CA-2 & $6 / 22 / 16$ & 0.7 & 0.9 & 136 & 8.1 & 7.9 & 1.9 & 0.12 & 0.08 & 7.5 & 5.3 \\
\hline$C A-3$ & $6 / 23 / 16$ & -6.8 & 0.9 & 151 & 8.6 & 2.4 & 0.8 & 0.30 & 0.11 & 35.4 & 9.3 \\
\hline NM & $6 / 26 / 16$ & -12.8 & 0.9 & 173 & 9.3 & 4.6 & 1.2 & 0.08 & 0.06 & 0.9 & 4.4 \\
\hline OR-1 & 4/29/16 & -11.0 & 0.9 & 135 & 8.1 & 26.4 & 5.4 & 0.04 & 0.05 & 1.4 & 4.5 \\
\hline OR-2 & $6 / 20 / 16$ & -7.3 & 0.9 & 137 & 8.1 & 23.6 & 4.9 & 0.10 & 0.07 & 3.3 & 4.7 \\
\hline
\end{tabular}


Table A-3. UOP-389 Results

\begin{tabular}{ccccc}
\hline State & Na, ppm & K, ppm & Ca, ppm & Mg, ppm \\
\hline FL-1 (fleet) & 0.14 & 0.04 & 0.08 & 0.01 \\
FL-2 & 0.04 & 0.01 & 0.05 & 0.01 \\
GA & 0.06 & 0.02 & 0.06 & 0.01 \\
NC-1 (fleet) & 0.06 & 0.01 & 0.09 & 0.02 \\
NC-2 & 0.02 & 0.01 & 0.02 & 0.01 \\
PA-1 & 0.09 & 0.01 & 0.05 & 0.02 \\
PA-2 (fleet) & 0.08 & 0.02 & 0.04 & 0.03 \\
MA & 0.04 & 0.01 & 0.04 & 0.01 \\
VA (fleet) & 0.08 & 0.02 & 0.06 & 0.02 \\
\hline IA (fleet) & 0.09 & 0.03 & 0.04 & 0.01 \\
IL & 0.07 & 0.01 & 0.03 & 0.01 \\
IN & 0.2 & 0.07 & 0.1 & 0.03 \\
KS & 0.09 & 0.02 & 0.53 & 0.06 \\
KY & 0.05 & 0.01 & 0.03 & 0.01 \\
MI & 0.11 & 0.02 & 0.06 & 0.01 \\
MN-1 & 0.04 & 0.01 & 0.04 & 0.01 \\
MN-2 & 0.02 & 0.01 & 0.03 & 0.01 \\
MO & 0.09 & 0.01 & 0.05 & 0.01 \\
OH-1 & 0.05 & 0.01 & 0.05 & 0.01 \\
OH-2 & 0.01 & 0.01 & 0.03 & 0.01 \\
TN-1 & 0.1 & 0.01 & 0.06 & 0.01 \\
TN-2 (fleet) & 0.24 & 0.02 & 0.08 & 0.01 \\
\hline LA & 0.04 & 0.01 & 0.03 & 0.01 \\
TX-1 & 0.06 & 0.01 & 0.08 & 0.01 \\
TX-2 & 0.07 & 0.01 & 0.04 & 0.01 \\
TX-3 & 0.04 & 0.01 & 0.03 & 0.01 \\
\hline CO & 0.09 & 0.01 & 0.05 & 0.01 \\
ID (fleet) & 0.22 & 0.03 & 0.12 & 0.03 \\
\hline AZ (fleet) & 0.07 & 0.01 & 0.04 & 0.01 \\
CA-1 & 0.05 & 0.02 & 0.03 & 0.01 \\
CA-2 & 0.07 & 0.01 & 0.04 & 0.01 \\
CA-3 (fleet) & 0.06 & 0.01 & 0.04 & 0.01 \\
NM & 0.1 & 0.02 & 0.05 & 0.01 \\
OR-1 & 0.06 & 0.02 & 0.03 & 0.02 \\
OR-2 & 0.05 & 0.01 & 0.05 & 0.01 \\
\hline & & & &
\end{tabular}


Table A-4. MP-AES results

\begin{tabular}{|c|c|c|c|c|c|}
\hline State & $\mathrm{Na}, \mathrm{ppm}$ & $\mathrm{K}, \mathrm{ppm}$ & Ca, ppm & $\mathrm{Mg}, \mathrm{ppm}$ & P, ppm \\
\hline FL-1 (fleet) & ND & 0.015 & 0.03 & 0.015 & ND \\
\hline $\mathrm{FL}-2$ & ND & ND & ND & 0.01 & ND \\
\hline $\mathrm{GA}$ & ND & 0.055 & 0.055 & 0.08 & ND \\
\hline NC-1 (fleet) & ND & ND & ND & ND & ND \\
\hline NC-2 & ND & ND & ND & ND & ND \\
\hline PA-1 & ND & ND & ND & ND & ND \\
\hline PA-2 (fleet) & ND & ND & ND & ND & ND \\
\hline MA & ND & ND & ND & ND & ND \\
\hline VA (fleet) & ND & ND & ND & ND & ND \\
\hline IA (fleet) & ND & 0.04 & ND & ND & ND \\
\hline IL & No Data & No Data & No Data & No Data & No Data \\
\hline IN & ND & 0.205 & ND & 0.005 & ND \\
\hline KS & 0.1 & 0.26 & 1.575 & 0.355 & 0.17 \\
\hline KY & ND & ND & ND & ND & ND \\
\hline $\mathrm{Ml}$ & ND & ND & 0.01 & 0.005 & ND \\
\hline $\mathrm{MN}-1$ & ND & ND & ND & ND & ND \\
\hline $\mathrm{MN}-2$ & ND & ND & ND & ND & ND \\
\hline $\mathrm{MO}$ & ND & ND & ND & ND & ND \\
\hline $\mathrm{OH}-1$ & No Data & No Data & No Data & No Data & No Data \\
\hline $\mathrm{OH}-2$ & ND & ND & ND & ND & ND \\
\hline TN-1 & ND & ND & ND & ND & ND \\
\hline TN-2 (fleet) & ND & ND & ND & ND & ND \\
\hline LA & ND & ND & ND & ND & ND \\
\hline TX-1 & ND & ND & ND & ND & ND \\
\hline TX-2 & ND & ND & ND & 0.005 & ND \\
\hline TX-3 & ND & ND & ND & ND & ND \\
\hline $\mathrm{CO}$ & ND & 0.03 & 0.045 & 0.01 & ND \\
\hline ID (fleet) & ND & 0.095 & 0.075 & 0.025 & ND \\
\hline AZ (fleet) & ND & ND & ND & ND & ND \\
\hline CA-1 & ND & 0.035 & ND & ND & ND \\
\hline CA-2 & ND & ND & ND & ND & ND \\
\hline CA-3 (fleet) & ND & ND & ND & ND & ND \\
\hline NM & ND & ND & ND & ND & ND \\
\hline OR-1 & ND & 0.03 & ND & ND & ND \\
\hline OR-2 & ND & ND & ND & ND & ND \\
\hline
\end{tabular}


Table A-5. ICP-MS Results.

\begin{tabular}{cccccc}
\hline State & Na, ppm & K, ppm & Ca, ppm & Mg, ppm & Fe, ppm \\
\hline FL-1 (fleet) & 0.029 & 0.021 & 0.008 & 0.026 & 0.065 \\
FL-2 & 0.029 & 0.033 & 0.002 & 0.014 & 0.146 \\
GA & 0.029 & 0.034 & 0.002 & 0.011 & 1.44 \\
NC-1 (fleet) & 0.029 & 0.02 & 0.002 & 0.01 & 0.004 \\
NC-2 & No Data & No Data & No Data & No Data & No Data \\
PA-1 & 0.029 & 0.014 & 0.002 & 0.009 & 0.012 \\
PA-2 (fleet) & 0.029 & 0.031 & 0.002 & 0.019 & 0.017 \\
MA & 0.029 & 0.02 & 0.002 & 0.015 & 0.016 \\
VA (fleet) & 0.029 & 0.028 & 0.012 & 0.011 & 0.086 \\
\hline IA (fleet) & 0.029 & 0.1 & 0.017 & 0.014 & 0.249 \\
IL & 0.029 & 0.02 & 0.007 & 0.019 & 0.005 \\
IN & 0.029 & 0.237 & 0.106 & 0.031 & 0.075 \\
KS & 0.029 & 0.11 & 1.366 & 0.166 & 1.557 \\
KY & 0.029 & 0.022 & 0.002 & 0.015 & 0.069 \\
MI & 0.029 & 0.045 & 0.122 & 0.025 & 3.117 \\
MN-1 & 0.029 & 0.016 & 0.002 & 0.025 & 0.172 \\
MN-2 & 0.029 & 0.016 & 0.002 & 0.048 & 0.003 \\
MO & 0.029 & 0.034 & 0.01 & 0.012 & 0.019 \\
OH-1 & 0.029 & 0.013 & 0.002 & 0.011 & 0.033 \\
OH-2 & 0.029 & 0.015 & 0.002 & 0.007 & 0.003 \\
TN-1 & 0.029 & 0.019 & 0.003 & 0.006 & 0.085 \\
TN-2 (fleet) & 0.029 & 0.029 & 0.012 & 0.009 & 0.361 \\
\hline LA & No Data & No Data & No Data & No Data & No Data \\
TX-1 & 0.029 & 0.01 & 0.002 & 0.005 & 0.003 \\
TX-2 & 0.029 & 0.012 & 0.002 & 0.006 & 0.004 \\
TX-3 & 0.029 & 0.011 & 0.002 & 0.005 & 0.004 \\
\hline CO & 0.029 & 0.023 & 0.094 & 0.035 & 0.037 \\
ID (fleet) & 0.029 & 0.085 & 0.065 & 0.034 & 0.044 \\
\hline AZ (fleet) & 0.029 & 0.085 & 0.065 & 0.034 & 0.044 \\
CA-1 (fleet) & 0.029 & 0.016 & 0.002 & 0.019 & 0.009 \\
CA-2 & 0.029 & 0.016 & 0.002 & 0.011 & 0.03 \\
CA-3 & 0.029 & 0.033 & 0.002 & 0.018 & 0.005 \\
NM & 0.029 & 0.025 & 0.002 & 0.005 & 0.284 \\
OR-1 & 0.029 & 0.012 & 0.002 & 0.005 & 0.009 \\
OR-2 & 0.029 & 0.021 & 0.002 & 0.005 & 0.011 \\
\hline & & & & &
\end{tabular}

